\title{
The influence of joint line position on functional outcome in primary total knee arthroplasty
}

\author{
Nikhil Gupta*, Rajesh Singh, Akash Saxena
}

Department of Orthopedics, Ruby Hall Clinic, Pune, Maharashtra, India

Received: 17 January 2021

Revised: 11 February 2021

Accepted: 18 February 2021

\author{
*Correspondence: \\ Dr. Nikhil Gupta, \\ E-mail: nik071990@gmail.com
}

Copyright: ( $)$ the author(s), publisher and licensee Medip Academy. This is an open-access article distributed under the terms of the Creative Commons Attribution Non-Commercial License, which permits unrestricted non-commercial use, distribution, and reproduction in any medium, provided the original work is properly cited.

\begin{abstract}
Background: To find out the cut off for position of joint line which will provide a good functional outcome.

Methods: 58 patients underwent total knee arthroplasty using standard medial parapatellar approach were included in this study. Pre-operative and post-operative radiological joint line were assessed. Pre-operative and post-operative functional assessment were done using oxford knee score and International knee society score. functional outcome was assessed at 1, 3 and 6 months. Influence of post-operative joint line change on functional outcome was assessed on follow up visit in $6^{\text {th }}$ month.

Results: Of 58 patients studied, mean age \pm SD was $69.0 \pm 7.5$ years. Joint line elevation of $36,16,8$ and 2 patients were between 0-2, 2-4 4-8 and $>8 \mathrm{~mm}$ respectively with mean \pm SD of joint line elevation of $2.24 \pm 2.07 \mathrm{~mm}$ in the group. Mean OKS-knee score at 6 months follow-up of study group was 36.60 with mean IKSS-knee score of 38.17 at 6 months follow up of group $<4 \mathrm{~mm}$ which was significant $(\mathrm{p}<0.05)$ when compared to mean IKSS-knee score at 6 months follow up of group $>4 \mathrm{~mm}$ (28.40).

Conclusions: It was concluded that joint line restoration is necessary for getting a good functional outcome after primary total knee arthroplasty. The functional outcome of patients with joint line elevation between 4-8mm showed inferior outcomes in comparison to the patients with joint line elevation within $4 \mathrm{~mm}$.
\end{abstract}

Keywords: Arthroplasty, Joint line, Functional outcome

\section{INTRODUCTION}

In patients who underwent total knee arthroplasty, the satisfaction level is between 75 to $90 \% .^{1-4}$ Restoration of joint line position is one factor that has been reported to be important influence on function outcome after total knee arthroplasty. ${ }^{5-7}$ Incorrect restoration of the original joint line can cause primarily pain, instability especially in mid flexion, motion limitation, and joint stiffness (decreased ROM) ${ }^{8}$ Surgical technique is important to restore the joint line, which includes the level of resection of tibia and posterior cruciate ligament preservation or sacrifice. ${ }^{9-11}$ In various previously done studies, functional outcomes have been linked to joint line placement. The effect of the joint line position on functional outcomes after total knee arthroplasty which are measured by the international knee society score (IKSS) is still controversial. ${ }^{12}$ The current study is done to find out the cut off for position of joint line which will be provide the good functional outcome.

\section{METHODS}

This study is a prospective observational study. The patients who underwent primary total knee arthroplasty in the department of orthopedics of Ruby hall clinic, Pune, during the period of October 2017 to January 2019 were considered as study participants. Inclusion for the study were-1) All patients who have pre-operative X-ray done within 1 month from surgery and post-operative X-rays done post operatively in Ruby hall clinic, Pune. 2) All 
patients above 40 years and below 80 years who are medically and surgically fit and can be followed for 6 months. Exclusion criteria for the study were-1) Patients below 40 years and above 80 years, 2) revision surgery, 3 ) previous h/o trauma to knee, 4) Patients who refused to be a part of this study, 5) Patients who got their pre-operative X-ray done from outside hospital, 6) Patients lost to follow up.

A total of 58 patients were included in this study. Preoperative radiological joint line was assessed in anteroposterior view of X-ray of knee to be operated taken within 1 month of surgery. All routine investigations were done. Informed consent from patients for participation in the study was taken. Pre-operative functional assessment was done using- Oxford knee score and International knee society score. ${ }^{12,13}$ Total knee arthroplasty was performed using standard medial parapatellar approach. Postoperative radiological joint line was assessed in antero-posterior view of X-ray of knee which was operated. Patients were followed up in 1 month, 3 months and 6 months post operatively. On every follow up, patient's functional outcome was assessed using oxford knee score and IKSS. Influence of post-operative joint line change on functional outcome was assessed on follow up visit in $6^{\text {th }}$ month.

The statistical significance of inter-group distribution of categorical variables is tested using chi-square test of Fisher's exact probability test. Intra-group comparisons of means of continuous variables are tested using repeated measures analysis of variance (RMANOVA) technique. $\mathrm{P}$ values less than 0.05 are considered to be statistically significant. The entire data is statistically analyzed using statistical package for social sciences (SPSS version 21.0, IBM Corporation, USA).

\section{Measurement of radiological elevation of joint line}

The joint line height was measured as the perpendicular distance between a line connecting the most distal points of the medial and lateral femoral condyles and a parallel line extending to fibular head on antero-posterior radiographs. ${ }^{14}$

Measurement of the joint line position change on the AP knee radiograph in Figure 1.

(A) a: preoperative joint line height. b: preoperative distance between the medial and lateral femoral epicondyles.

(B) c: postoperative joint line height. d: postoperative distance between the medial and lateral femoral epicondyles.

The difference between pre-operative and post-operative joint line was calculated as:

$\mathrm{D}=(\mathrm{b} / \mathrm{d}) \mathrm{a}-\mathrm{c}$

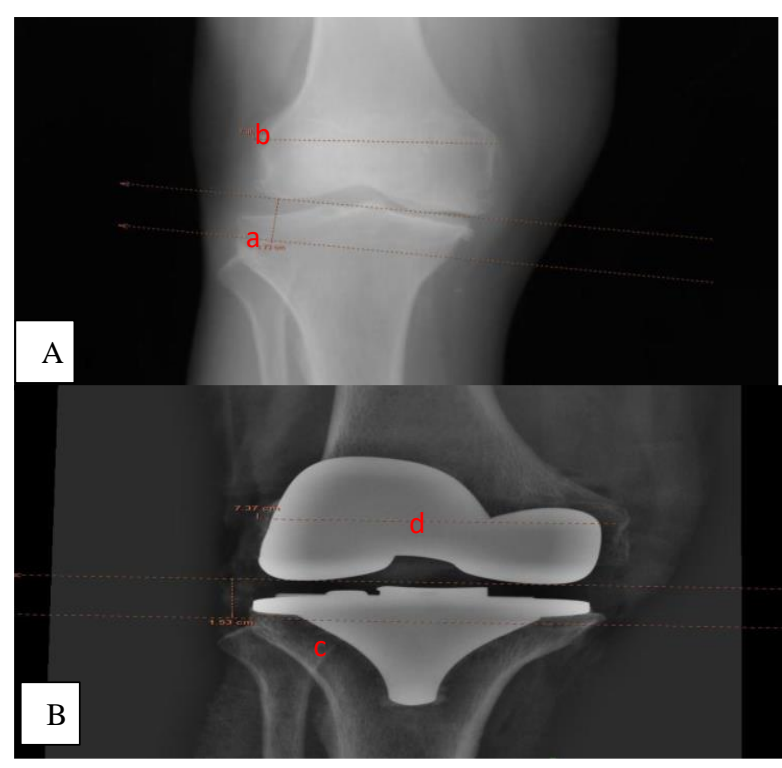

Figure 1: (A) pre- and (B) post-operative radiological measurement of joint line position change

\section{RESULTS}

Of 58 patients studied, 8 had age below 60 years, 23 had age between 60- 69 years, 27 had age between $70-80$ years with mean age of $69.0 \pm 7.5$ years, 26 were male and 32 were female. Mean BMI in the study group was $27.6 \pm 3.5$ $\mathrm{kg} / \mathrm{m}^{2}$ with 31 were found overweight and 15 were found obese. 27 patients had left side involved, 27 had right side involved and 4 had bilateral involvement.

Table 1: Demographic details.

\begin{tabular}{|ll|}
\hline Characteristic & No. of patients \\
\hline Age (years) & \\
\hline$<60$ & 8 \\
\hline $60-69$ & 23 \\
\hline$>70$ & 27 \\
\hline Male/Female & $26 / 32$ \\
\hline BMI (kg/m ${ }^{2}$ mean & 27.6 \\
\hline Side (right/left/bilateral) & $27 / 27 / 4$ \\
\hline
\end{tabular}

Of 62 cases studied, 36 had joint line elevation between 0 $2 \mathrm{~mm}, 16$ had joint line elevation between $2-4 \mathrm{~mm}, 8$ had joint line elevation between $4-8 \mathrm{~mm}$ and 2 had joint line elevation more than $8 \mathrm{~mm}$ in the study group with mean \pm $\mathrm{SD}$ of joint line elevation of $2.24 \pm 2.07 \mathrm{~mm}$ in the group.

The mean \pm SD of IKSS and OKS at pre-op in group of cases with joint line elevation between 0-2 $\mathrm{mm}$ was $54.22 \pm 5.92$ and $18.56 \pm 3.88$ respectively, which progress at 6 months follow-up to $82.69 \pm 6.43$ and $39.94 \pm 3.76$ respectively. Similar progress was seen with group of joint line elevation between 2-4, 4-8 and >8 $\mathrm{mm}$ when pre-op score compared at score at 6 months (Table 2). But maximum increase in IKSS and OKS score seen with joint line elevation $<2 \mathrm{~mm}$. It was also observed that low IKSS at pre-op results in low increase of IKSS after 6 months. 
Table 2: Joint line elevation (mm).

\begin{tabular}{|c|c|c|c|c|c|c|c|c|c|c|}
\hline $\begin{array}{l}\text { Joint line } \\
\text { elevation }\end{array}$ & \multicolumn{2}{|c|}{$0-2 \mathrm{~mm}$} & \multicolumn{2}{|l|}{ 2-4 mm } & \multicolumn{2}{|l|}{$4-8 \mathrm{~mm}$} & \multicolumn{2}{|l|}{$>8 \mathrm{~mm}$} & \multicolumn{2}{|c|}{ Overall } \\
\hline No. of patients & 36 & & 16 & & 8 & & 2 & & 62 & \\
\hline IKSS & Mean & SD & Mean & SD & Mean & SD & Mean & SD & Mean & SD \\
\hline Pre-op & 54.22 & 5.92 & 52.69 & 3.96 & 46.63 & 8.78 & 44.50 & 3.54 & 52.53 & 6.43 \\
\hline 1 month & 77.83 & 6.89 & 69.25 & 4.20 & 64.13 & 5.11 & 57.50 & 0.71 & 73.19 & 8.38 \\
\hline 3 months & 80.61 & 6.62 & 72.13 & 3.57 & 66.25 & 5.06 & 59.00 & 0.00 & 75.87 & 8.35 \\
\hline 6 months & 82.69 & 6.43 & 73.88 & 3.48 & 67.50 & 5.21 & 60.00 & 2.83 & 77.73 & 8.52 \\
\hline \multicolumn{11}{|l|}{ OKS } \\
\hline Pre-op & 18.56 & 3.88 & 17.44 & 2.42 & 13.38 & 2.26 & 11.50 & 2.12 & 17.37 & 3.85 \\
\hline 1 month & 35.14 & 3.83 & 30.25 & 2.98 & 25.50 & 2.33 & 21.00 & 0.00 & 32.18 & 5.23 \\
\hline 3 months & 37.17 & 3.74 & 32.06 & 2.82 & 27.38 & 2.45 & 22.50 & 0.71 & 34.11 & 5.26 \\
\hline 6 months & 39.94 & 3.76 & 34.19 & 3.10 & 29.38 & 2.26 & 24.50 & 0.71 & 36.60 & 5.55 \\
\hline
\end{tabular}

Table 3: Distribution of functional outcome based on IKSS at 6-month follow-up according to joint line elevation among cases.

\begin{tabular}{|llllll|}
\hline \multirow{2}{*}{ IKSS } & Joint line elevation $(\mathbf{m m})$ & \\
& $\mathbf{0 - 2}$ & $\mathbf{2 - 4}$ & $\mathbf{4 - 8}$ & $\mathbf{> 8}$ & Overall \\
\hline Poor & 0 & $\mathbf{n}=\mathbf{1 6}$ & $\mathbf{n = 8}$ & $\mathbf{n = 2}$ & \\
\hline Fair & 1 & 1 & 4 & 1 & 2 \\
\hline Good & 12 & 14 & 3 & 0 & 29 \\
\hline Excellent & 23 & 1 & 0 & 0 & 24 \\
\hline
\end{tabular}

Table 4: Distribution of functional outcome based on OKS at 6-month follow-up according to joint line elevation among the cases.

\begin{tabular}{|c|c|c|c|c|c|}
\hline \multirow{2}{*}{$\begin{array}{l}\text { Variables } \\
\text { OKS score } \\
\text { (6-months) }\end{array}$} & \multicolumn{5}{|c|}{ Joint line elevation (mm) } \\
\hline & $\begin{array}{l}0-2 \\
n=36\end{array}$ & $\begin{array}{l}2-4 \\
n=16\end{array}$ & $\begin{array}{l}4-8 \\
n=8\end{array}$ & $\begin{array}{l}>8 \\
n=2\end{array}$ & $\begin{array}{l}\text { Over } \\
\text { all }\end{array}$ \\
\hline $\begin{array}{l}\text { Severe knee } \\
\text { arthritis (0- } \\
19)\end{array}$ & 0 & 0 & 0 & 0 & 0 \\
\hline $\begin{array}{l}\text { Moderate to } \\
\text { severe knee } \\
\text { arthritis (20- } \\
\text { 29) }\end{array}$ & 0 & 0 & 4 & 2 & 6 \\
\hline $\begin{array}{l}\text { Mild to } \\
\text { moderate } \\
\text { knee arthritis } \\
(30-39)\end{array}$ & 14 & 16 & 4 & 0 & 34 \\
\hline $\begin{array}{l}\text { Satisfactory } \\
\text { joint } \\
\text { function (40- } \\
48)\end{array}$ & 22 & 0 & 0 & 0 & 22 \\
\hline
\end{tabular}

As shown in Table 3, 24 patients had excellent results, 29 had good, 7 had fair while 2 patients had poor functional outcome. Since the proportion of cases with good or excellent outcome is significantly higher in the group of cases with joint line elevation 0-2 mm compared to group of cases with joint line elevation more than $2 \mathrm{~mm}$ $(\mathrm{p}<0.001)$, it can be concluded that the functional outcome based on international knee society score (IKSS) and Oxford knee score (OKS) at 6-month follow-up (Table 4) is significantly better in the group of cases with joint line elevation 0-2 mm compared to the other joint line elevation groups (more than $2 \mathrm{~mm}$ ) in the study group $(\mathrm{p}<0.001$ for all).

\section{DISCUSSION}

Total knee Arthroplasty is one of the most successful surgical procedures performed. While patient related factor cannot be changed, surgical related factors can be controlled. Anatomic restoration of the joint line level during surgery is one of the key factors to provide appropriate connective tissue balance and normal knee kinematics and to obtain satisfactory results after total knee arthroplasty. ${ }^{14}$ Joint line elevation can lead to decreased range of motion (ROM), decreased lever arm, extensor lag, impingement of the patella against the tibial polyethylene or tibial plate, anterior knee pain, increased energy expenditure, and rupture of the patellar or quadriceps tendons. ${ }^{1,28,8,15-21}$ In addition, lowering of the joint line has been associated with retropatellar pain and increased rates of patellar subluxation and it has been suggested that increased patellar strain might also result. ${ }^{19,20,22}$

Various authors in the past have linked functional outcome to joint line placement. This study compared the change in joint line level and its influence on functional outcome using IKSS and OKS score. It also tried to give cut off for joint line elevation that will result in good functional outcome.

Selvarajah et al did a prospectively study in 76 patients and assessed for a minimum of 2.5 years and found that the joint line was elevated $1 \mathrm{~mm}$ on average (range, -11 to +10 ) and concluded that no correlation between joint line position and range of motion, knee function scores, knee 
pain scores, or patellar height. ${ }^{23}$ They defended that up to $10 \mathrm{~mm}$, a change in the joint line had no effect on any clinical result. Partington et al study 99 revision TKAs and found a very marginal statistical difference in clinical score with more than $8 \mathrm{~mm}$ of joint line elevation and where a direct correlation between joint line elevation and clinical performance was not found. ${ }^{24}$ Snider et al too supported same. ${ }^{25}$

However, many authors consider restoring joint line level as key factor for functional outcome. Figgie et al concluded that joint line elevation $<8 \mathrm{~mm}$ is associated with favourable outcome and imbalance of extensor mechanism occur with elevation $>8 \mathrm{~mm} .{ }^{26}$ Yang et al stated that patients tolerated elevation up to $5 \mathrm{~mm}$ well and shown no difference in functional outcome. ${ }^{27}$

In our study, mean joint line elevation was $2.24 \mathrm{~mm}$ with 52 (80) \% of patients had joint line elevation less than 4 $\mathrm{mm}$ which was comparable to various study. ${ }^{28-30}$ Mean IKSS-knee score at 6 months follow up of study group was 77.73 with mean IKSS-knee score at 6 months follow up of group $<4 \mathrm{~mm}$ was 79.96 which was significant $(\mathrm{p}<0.05)$ when compared to mean IKSS-knee score at 6 months follow up of group $>4 \mathrm{~mm}$ (66.00). These results were comparable to various authors. ${ }^{29-32}$

In our study, mean OKS-knee score at 6 months follow-up of study group was 36.60 with mean IKSS-knee score of 38.17 at 6 months follow up of group $<4 \mathrm{~mm}$ which was significant $(\mathrm{p}<0.05)$ when compared to mean IKSS-knee score at 6 months follow up of group $>4 \mathrm{~mm}$ (28.40). These results were comparable to various authors. ${ }^{28,31}$

\section{CONCLUSION}

From our study we concluded that joint line restoration is necessary for getting a good functional outcome after primary total knee arthroplasty. The functional outcome with patients with joint line elevation within $4 \mathrm{~mm}$ is good. The functional outcome with patients with joint line elevation between $4-8 \mathrm{~mm}$ showed inferior outcomes in comparison to the patients with joint line elevation within $4 \mathrm{~mm}$. International knee society score and oxford knee score are excellent and reliable scoring techniques for assessing functional outcome of knee.

\section{Funding: No funding sources}

Conflict of interest: None declared

Ethical approval: The study was approved by the institutional ethics committee

\section{REFERENCES}

1. Bourne RB, Chesworth BM, Davis AM, Mahomed NN, Charron KD. Patient satisfaction after total knee arthroplasty: who is satisfied and who is not? Clin Orthop Rel Res. 2010;468(1):57-63.

2. Choi YJ, Ra HJ. Patient satisfaction after total knee arthroplasty. Knee surg rel res. 2016;28(1):1.
3. Clement ND, Bardgett M, Weir D, Holland J, Deehan DJ. Increased symptoms of stiffness 1 year after total knee arthroplasty are associated with a worse functional outcome and lower rate of patient satisfaction. Knee Surg, Sports Traumatol Arthroscopy. 2019;27(4):1196-203.

4. Lange JK, Lee YY, Spiro SK, Haas SB. Satisfaction rates and quality of life changes following total knee arthroplasty in age-differentiated cohorts. J arthroplasty. 2018;33(5):1373-8.

5. Goldberg VM, Heiple KG, Gordon NH. The influence of tibial-patellofemoral location on function of the knee in patients with the posterior stabilized condylar knee prosthesis. J bone joint surg Am. 1986;68(7):1035-40.

6. Emodi GJ, Callaghan JJ, Pedersen DR, Brown TD. Posterior cruciate ligament function following total knee arthroplasty: the effect of joint line elevation. Iowa orthop j. 1999;19:82.

7. Cope MR, O'brien BS, Nanu AM. The influence of the posterior cruciate ligament in the maintenance of joint line in primary total knee arthroplasty: a radiologic study. J arthroplasty. 2002;17(2):206-8.

8. Wyss TF, Schuster AJ, Münger P, Pfluger D, Wehrli U. Does total knee joint replacement with the soft tissue balancing surgical technique maintain the natural joint line? Archives of orthopaedic and trauma surgery. 2006;126(7):480-6.

9. Ritter MA, Montgomery TJ, Zhou H, Keating ME, Faris PM, Meding JB. The clinical significance of proximal tibial resection level in total knee arthroplasty. Clin Orthop Rel Res. 1999;360:174-81.

10. Porteous AJ, Hassaballa MA, Newman JH. Does the joint line matter in revision total knee replacement? J bone joint surg Bri. 2008;90(7):879-84.

11. Mihalko WM, Krackow KA. Posterior cruciate ligament effects on the flexion space in total knee arthroplasty. Clin Orthop Rel Res. 1999;360:243-50.

12. Insall JN, Dorr LD, Scott RD, Scott WN. Rationale of the Knee Society clinical rating system. Clin Orthop relat res. 1989;248(248):13-4.

13. Dawson J, Fitzpatrick R, Murray D, Carr A. Questionnaire on the perceptions of patients about total knee replacement. J bone joint surg Bri. 1998;80(1):63-9.

14. Lee KJ, Moon JY, Song EK, Lim HA, Seon JK. Minimum two-year results of revision total knee arthroplasty following infectious or non-infectious causes. Knee surg rel res. 2012;24(4):227.

15. Hofmann AA, Kurtin SM, Lyons S, Tanner AM, Bolognesi MP. Clinical and radiographic analysis of accurate restoration of the joint line in revision total knee arthroplasty. J arthroplasty. 2006;21(8):1154-62.

16. Chonko DJ, Lombardi JA, Berend K. Patella Baja and total knee arthroplasty (TKA): etiology, diagnosis, and management. Surgical technol int. 2004;12:2318.

17. Weale AE, Murray DW, Newman JH, Ackroyd CE. The length of the patellar tendon after uni- 
compartmental and total knee replacement. $\mathrm{J}$ bone joint surg Bri. 1999;81(5):790-5.

18. Choudhary P, Bahre S. Influence of prosthetic joint line position on outcome after total knee replacement. Int J Res Orthop. 2017;3(5):951.

19. Insall J, Goldberg V, Salvati E. Recurrent dislocation and the high-riding patella. Clin Orthop Rel Res. 1972;88:67-9.

20. Lancourt JE, Cristini JA. Patella Alta and patella infera. Their etiological role in patellar dislocation, chondromalacia, and apophysitis of the tibial tubercle. J bone joint surg Am. 1975;57(8):1112-5.

21. Martin JW, Whiteside LA. The influence of joint line position on knee stability after condylar knee arthroplasty. Clin orthop rel res. 1990;259:146-56.

22. Singerman R, Heiple KG, Davy DT. Effect of tibial component position on patellar strain following total knee arthroplasty. J Arthroplasty 1995;10:651.

23. Selvarajah E, Hooper G. Restoration of the joint line in total knee arthroplasty. J arthroplasty. 2009;24(7):1099-102.

24. Partington PF, Sawhney J, Rorabeck CH, Barrack RL, Moore J. Joint line restoration after revision total knee arthroplasty. Clin orthop rel res. 1999;367:165-71.

25. Snider MG, MacDonald SJ. The influence of the posterior cruciate ligament and component design on joint line position after primary total knee arthroplasty. J arthroplasty. 2009;24(7):1093-8.

26. Figgie HE. The influence of tibial-patellofemoral location on function of the knee in patients with the posterior stabilized condylar knee prosthesis. J Bone Joint Surg Am. 1986;68(7):1035-40.

27. Yang JH, Seo JG, Moon YW, Kim MH. Joint line changes after navigation-assisted mobile-bearing TKA. Orthopedics. 2009;32(10):35-9.
28. Goh GS, Liow MH, Lim WS, Tay DK, Yeo SJ, Tan $\mathrm{MH}$. Accelerometer-based navigation is as accurate as optical computer navigation in restoring the joint line and mechanical axis after total knee arthroplasty: a prospective matched study. J arthroplasty. 2016;31(1):92-7

29. Lee HJ, Lee JS, Jung HJ, Song KS, Yang JJ, Park CW. Comparison of joint line position changes after primary bilateral total knee arthroplasty performed using the navigation-assisted measured gap resection or gap balancing techniques. Knee Surgery, Sports Traumatology, Arthroscopy. 2011;19(12):2027-32.

30. Liow MH, Xia Z, Wong MK, Tay KJ, Yeo SJ, Chin PL. Robot-assisted total knee arthroplasty accurately restores the joint line and mechanical axis. A prospective randomised study. J arthroplasty. 2014;29(12):2373-7.

31. Pang HN, Yeo SJ, Chong HC, Chin PL, Chia SL, Lo NN. Joint line changes and outcomes in constrained versus unconstrained total knee arthroplasty for the type II valgus knee. Knee Surg Sports Traumatol Arthroscopy. 2013;21(10):2363-9.

32. Bae DK, Song SJ, Park CH, Liang H, Bae JK. Comparison of mid-term results between conversion total knee arthroplasties following closed wedge high tibial osteotomy and primary total knee arthroplasties: a matched pair study including patellar symptom and position. J Orthop Sci. 2017;22(3):495-500.

Cite this article as: Gupta N, Singh R, Saxena A. The influence of joint line position on functional outcome in primary total knee arthroplasty. Int J Res Orthop 2021;7:526-30. 